\title{
Fund Company's Equity Structure Effects on Fund Performance
}

\author{
Shu Ke Dong*, Yin Xiao Xue, Dai MingXi, Zhang Bin \\ Faculty of Economics, Hefei University of Technology, China
}

Copyright (C) 2015 by authors, all rights reserved. Authors agree that this article remains permanently open access under the terms of the Creative Commons Attribution License 4.0 International License

\begin{abstract}
It is well known that the equity structure of listed companies have effects on the company performances to some extent. However, the fund company is one special kind of financial enterprise and the relationship between its unique equity structure and fund performance still remains in suspense. On the basis of theoretical conjectures and results of predecessors, the development history of equity structure of Chinese fund company is analyzed and the fund evaluation methods are discussed in this paper which is based on the risk adjustment of excess return. Through sieving and accounting data, we conducted an empirical study about the effects of equity structure and regional feature on fund performance. The conclusions can be drew as that the fund company with foreign capital shows no signs of highlights and we found that concentrated shareholding and national resources are beneficial to improving fund performance level. In addition, the operating time and the fund company's location, investment fund's average tenure also have influences on fund performance.
\end{abstract}

Keywords Equity Structure, Regional Feature, Fund Performance, Regional Feature

\section{Introduction}

\subsection{Background and Significance}

Securities investment fund (hereafter referred to simply as fund) is a kind of independent and acceptable asset which combined the indeterminacy investor's funds through fund share selling. The fund is trusted by fund custodian, managed by professional fund manager and it also can be viewed as a collective investment behavior, which is benefit-sharing and risk-sharing, carried through investment portfolio. This kind of indirect investment is quite different from stock and bond investment. Principal-agent The problem of normal investor's lacking of professional knowledge is solved, and the unsystematic risk is dispersed under the principal-agent by balancing the scales of investment stock, bond and monetary fund with the assurance of reasonable return rate.

According to the Wind database statistics, by the end of March 2015, 96 fund companies have been established and 3088 fund products been issued in total in China. The net value and circulation development ${ }^{1}$ of fund in the market are showed under the following figure.

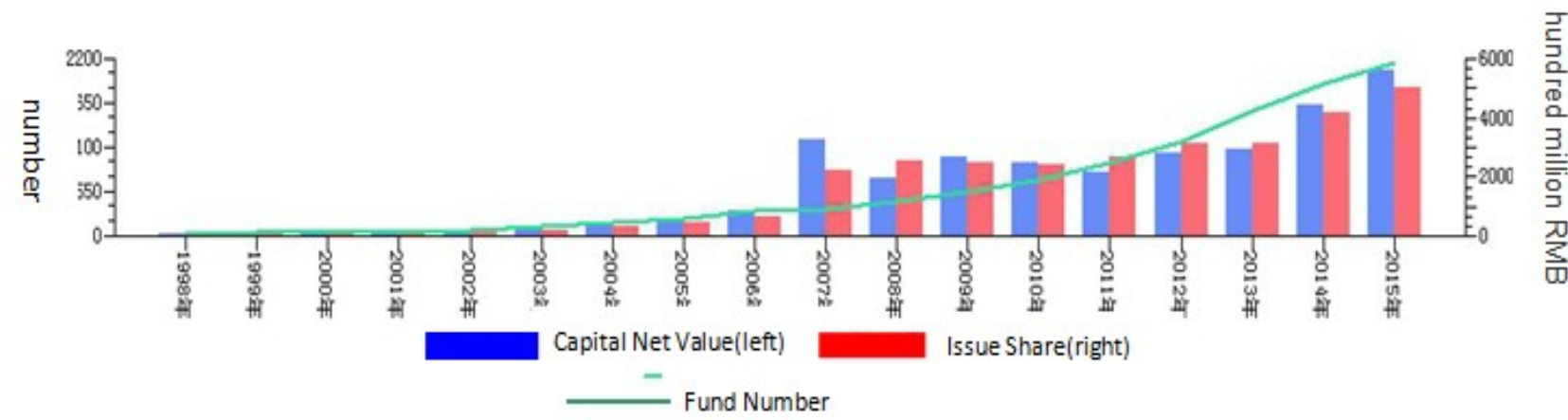

Figure 1. The development of fund market 
Behind the prosperity of overall numbers there still exist some inevitable problems such as principal-agent problem. For instance, Chinese stock market has stepped into a period of deep change due to the bad expectation of International market since the early $2011^{[1]}$. By September $30^{\text {th }} 2011$, Shanghai Composite Index has been shocked from 2852.65 to 2359.22 , dropped $493.43(17.29 \%)$. At the same time, SSE Fund Index has dived an accumulative $14.53 \%$, slightly lower the drawdown of stock market and consumer expectation. Another example shows that from March $3^{\text {rd }}$ 2014 to March $2^{\text {nd }} 2015$, Shanghai Composite Index gained $60.76 \%$ and reached 1261.04 , but at the same period SSE Fund Index reached 1856.36 , only gained $49.29 \%$.So that we can see the comprehensive achievement of fund even lower the whole market index. The aim of fund investment is for a better resource allocation which can achieve higher returns and lower risks. However, there still exist some gaps between the current Chinese fund performances and investor's expectations. The investment fund manager's incomes are still gainful whether the fund lost or lower than stock gains, which lead to the reveal of principal-agent problems.

\subsection{Domestic and International Research Situation}

1.2.1. Relevant researches of fund management company's equity effects on fund performance

The main type of foreign fund company is corporate-type, while it's almost contract-model in China, which leads to a great difference between the methods and results of equity structure and fund performance researches. Even research object that all Chinese companies taken is the same, the conclusions from different studies are often inconsistent.

Generally speaking, a certain extent concentration of equity structure is beneficial to company's making decisions and improving performance level. Randall Morck, Masao Nakamura and Anil shivdasani (2000) carried out a study about Japanese listed company ${ }^{[2]}$. The result shows that within a certain range, the more bank holds company stock shares, the better the company performance is. But once beyond the range, with the increase of shareholding ratio, the company performance becomes lower. Considering the different governance structures between the fund companies and ordinary companies, Robert F. Radin and William B. Stevenson (2005) came up a new point which says that based on the fund company's features ${ }^{[3]}$. We should strengthen independent director's supervision and shareholder's function so that we can enhance achievement and improve performance. According to the research of Qi Chen, Itay Goldstein and Wei Jiang (2005), the equity structures of fund company are related to the fund performance evaluation results of forecaster(Xing Chen) ${ }^{[4]}$. They find that different equity structures will significantly contribute to different company performance. Besides, the concentration of equity structure, small-scale of board and a larger proportion of independent board can reduce the relative rates.

Domestic research results show different viewpoints about particularity of Chinese capital market and Chinese basic condition. Li Xuefeng and Zhang Jian (2008) at Nankai university found that the factors such as the number of fund company shareholders, and the equity ownership of the largest shareholder and financial companies all have a positive role on fund performance ${ }^{[5]}$. Further, they proposed an equity structure which can optimize fund performance based on the findings. At the same year, Zhang Bin and Lin Sheng (2008) showed that the performance of fund companies is better when it compared with holding company and they supposed that a moderate increase in foreign capital shareholders will play an active role in enhancing fund performance ${ }^{[6]}$. As for the state-controlled enterprises, Jiang Ping, Tian Shu and Cheung Yan-Leung (2011) build a panel data measure model and draw the conclusion that the fund performance of state-controlled enterprises and Chinese-foreign joint ventures are much more better, which means ' the helping hand of national resources' does really exit $^{[7]}$. However, through the empirical analysis, Gao Yuan (2012) found that foreign shareholders are not favorable for enhancing fund performance ${ }^{[1]}$. What's more, with the increase of equity concentration and securities company's stock shares, fund manager's ability of market timing and stock picking decreased.

It is found that documents of researching fund companies are not only less than normal companies, but also some results of study of fund companies are inconsistent, after collection of research documents and materials. So, further studies about predecessors' results of study are carried on and real factors affecting performance of fund companies are also tried to be found in this paper.

\subsubsection{The related researches of Performance Evaluation method}

Sharpe (1966) used standard deviation to replace $\beta$ of Treynor's index with the risk-adjusted basis ${ }^{[8]}$. However, the Treynor index may not be applicable when it comes to the situation of market descending tendency and this point was questioned by Jobson and Korkie(1981) ${ }^{[9]}$. In addition, Israelsen (2005) pointed that the fitting degree of traditional Sharpe index in bear markets is pretty low so that he corrected Sharpe index, replaced it with the product of excess earnings and risks and found it fits better than traditional index ${ }^{[10]}$.

In recent years, domestic scholars combined foreign experience with Chinese condition and made a variety of improvements. In 2002, some researchers used RAROC method in the evaluation of fund performance. Hui Xiaofeng and Chi Wei (2002) collected 33 closed-end funds and conducted empirical research in fund performance by four quarters of $2009^{[11]}$. They found that there was a great difference between the research result and the direct evaluation of yields. Now that the researcher assumed that samples meet normal distribution condition, the experimental accuracy needs to be improved. Based on VaR, Xu Cuipin, Shi Qinghua and Shi Zhenghua(2007) built a fund performance evaluation model and further tested it, which showed that this model can overcome the defects of the traditional methods and has a better predicting ability ${ }^{[12]}$. 


\section{Empirical Analysis of Fund Company Equity Structure Effect on Fund Performance}

\subsection{Selection of Period and Sample Data}

In order to make research results more valuable, authors collect the five years data from 2010 to 2015 to be close the actual condition. Because the net asset value of fund is used in the following parameter settings contents and these data are mainly revealed in the fund company's quarterly reports, we chose the quarterly data as the research data. From the second quarter of 2010 to the first quarter of 2015, we collected 20 period data altogether. In practical application, we regarded the second quarterly data as the initial data since it's similar to yield calculation so that actually we got 19 periods.

In view of numerous of fund companies, fund companies are selected as sample size in the following criterion, namely, investment ways of fund and operation time of fund which better embody equity structure's impact on fund performance.

As it mentioned above, there are 96 fund companies are under operation in China and we selected the top 40 due to the Wind Information. The process of how the representative funds of each company are showed as the following flow chart.

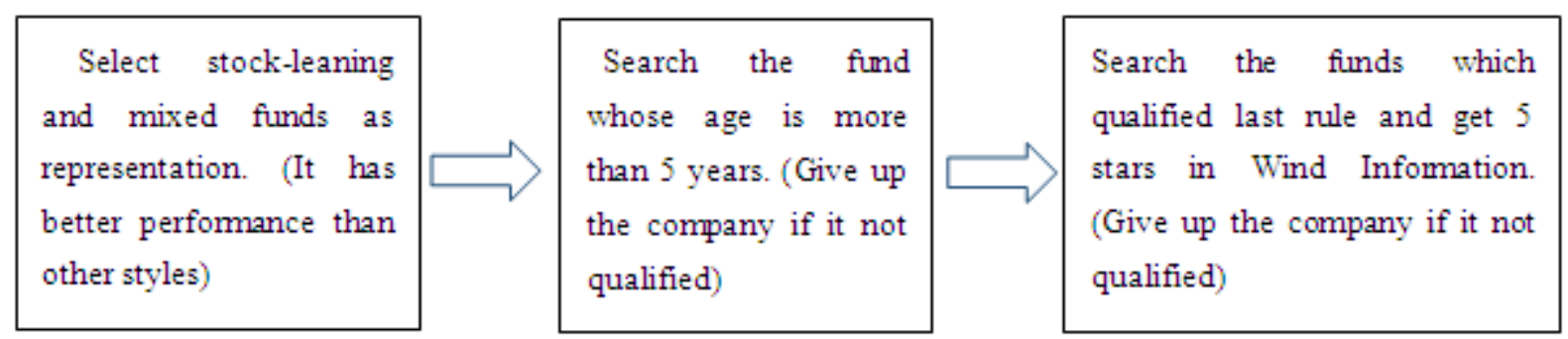

Figure 2. Flow chart of selecting sample fund

After the above process of selecting sample fund, there are 30 fund companies and its funds are chosen as the samples, which are showed as the following table:

Table 1. Fund companies and its corresponding fund

\begin{tabular}{cc}
\hline Fund Company(ordered by name) & Representative Fund Name \\
Baoying Fund Management Co.,Ltd. & Baoying core strength A \\
Bosera Asset Management Co.,Ltd. & Bosera value increase \\
Great Wall Fund Management Co.,Ltd. & Great Wall Double Motivation \\
Da Cheng Fund Management Co., Ltd & Da Cheng Hushen300 \\
Fullgoal Fund Management Co.,Ltd & Fullgoal Tianhui selected growth \\
GF Fund Management Co.,Ltd & GFHushen300 \\
GuoTai Asset Management Co.,Ltd & GuoTai Small-mid cap growth \\
UBS SDIC Fund Management Co., Ltd. & UBS SDIC and well-off \\
Hua An Fund Management Co.,Ltd & Hua An Shangzheng 180ETF \\
Fortune SG Fund Management Co.,Ltd & Fortune SG Advanced growth \\
Huashang Fund Management Co.,Ltd & Huashang prosperous times growth \\
China Asset Management Co.,Ltd. & China Small-middle cap ETF \\
China Universal Asset Management Co.,Ltd & China Universal Private vitality \\
Jiashi Fund Management Co.,Ltd. & Jiashi strategic growth \\
CCB Principal Asset Management Co.,Ltd. & Jianxin core selected \\
Bank of Communications Schroder Fund Management Co.,Ltd & Bocom sound configuration mixing \\
Invesco Great Wall Fund Management Company Limited & Invesco Great Wall preferred stock \\
China Southern Fund Management Co., Ltd. & China Southern500ETFconnection \\
Lion Fund Management Co., ltd & Lion flexible configuration \\
Penghua Fund Management Co., Ltd. & Penghua prosperous times innovation \\
Rongtong Fund Management Co., Ltd. & Longtop leading growth \\
E Fund Management Co., Ltd. & E Fund Shenzhen 100ETF \\
China International Fund Management Co., Ltd. & China International Fund Alpha \\
Rainbow Fund Management Co., Ltd. & Rainbow selection \\
Aegon-Industrial Fund Management Co.,Ltd. & Xingquan social responsibility \\
Yinhua Fund Management Co., Ltd. & Yinhua leading strategy \\
China Merchants Fund Management Co.,Ltd & Merchants Antai stock \\
Zhongou Fund Management Co., Ltd. & Zhongou industry growth \\
Zhongyin Fund Management Co., Ltd. & Zhongyin earnings \\
China Post\& Capital Fund Management Co.,Ltd. & China Post core topic \\
\hline
\end{tabular}




\subsection{The Selection and Definition of Variable}

The samples include 30 funds and time span is 19 quarters, so authors think it necessary to provide the first fund company as example and make a critical analysis in this paper. Authors can provide other data in the following pages in case some readers need.

Table 2. Relative performance data of BaoYing core strength A

\begin{tabular}{cccc}
\hline Report Period & Yields & VaR & RAROC Correction \\
\hline 2010 Middle Report & -0.173719099 & 1.962010282 & -0.351874966 \\
2010 Three Quarters Report & 0.119845169 & 1.585171141 & 0.072055418 \\
2010 Annual Report & 0.027996706 & 1.47623431 & 0.014307828 \\
2011 First Quarter Report & -0.007605929 & 1.37131556 & -0.020714996 \\
2011 Middle Report & -0.0578039 & 0.848725782 & -0.055955557 \\
2011 Three Quarters Report & -0.135938485 & 1.640625968 & -0.237379685 \\
2011 Annual Report & -0.043764467 & 0.691723878 & -0.036325511 \\
2012 First Quarter Report & -0.015024388 & 1.06779633 & -0.025386205 \\
2012 Middle Report & -0.018585564 & 0.404836914 & -0.010813422 \\
2012 Three Quarters Report & 0.009392967 & 1.627587741 & 0.001163051 \\
2012 Annual Report & 0.024105695 & 1.413636034 & 0.011746797 \\
2013 First Quarter Report & 0.138139568 & 1.446824207 & 0.090294016 \\
2013 Middle Report & 0.055433606 & 2.748504769 & 0.017439885 \\
2013 Three Quarters Report & 0.167011756 & 1.47813549 & 0.107914164 \\
2013 Annual Report & 0.002402823 & 2.433924853 & -0.012406147 \\
2014 First Quarter Report & 0.042588646 & 2.581298574 & 0.013593408 \\
2014 Middle Report & 0.06879996 & 1.876958589 & 0.032659197 \\
2014 Three Quarters Report & 0.147927921 & 2.022610287 & 0.069429055 \\
2014 Annual Report & 0.179619944 & 4.192445484 & 0.041203862 \\
2015 First Quarter Report & 0.154571284 & 2.941117065 & 0.050430255 \\
\hline
\end{tabular}

Table 3. Name and definition of variable

\begin{tabular}{|c|c|c|}
\hline Variable Name & Variable Definition & Remark \\
\hline G & $\begin{array}{l}\text { Whether the fund company } \\
\text { is state holding or not. }\end{array}$ & $\begin{array}{l}\text { G is dummy variable. When the 'final fund company's largest } \\
\text { shareholder' is central government, central government or } \\
\text { SASAC, we define the fund company as national holding company } \\
\text { and the G value equal to } 1 \text {, otherwise equal to } 0 \text {. }\end{array}$ \\
\hline W & $\begin{array}{l}\text { Whether the company is } \\
\text { joint venture or not. }\end{array}$ & $\begin{array}{l}\mathrm{W} \text { is dummy variable. When the shareholder of fund company } \\
\text { contain foreign capital, we define the fund company as joint } \\
\text { venture company and the } \mathrm{W} \text { value equal to } 1 \text {, otherwise equal to } 0 \text {. }\end{array}$ \\
\hline HHI & $\begin{array}{l}\text { The equity structure } \\
\text { concentration. }\end{array}$ & $\begin{array}{l}\text { Normally the number of fund company shareholder is less than } 8 \text {, } \\
\text { usually equal to } 3 \text { or } 4 \text {. The autocorrelation exists if we select } \\
\text { variable like the first big shareholder, second big shareholder, } \\
\text { thirdly big shareholder or shareholder number. After referencing } \\
\text { the definition of Herfindahl exponent, we introduced equity } \\
\text { structure concentration system and built HHI index, which equal to } \\
\text { the sum of squares of each shareholder's shareholding ratio. The } \\
\text { index is between } 0 \text { and } 1 \text { and the more it approaches } 1 \text {, the higher } \\
\text { equity concentration it has. }\end{array}$ \\
\hline Size & Fund company size & The data come from Morningstar.com. \\
\hline Age & $\begin{array}{l}\text { Fund company establish } \\
\text { age }\end{array}$ & The data come from Morningstar.com. \\
\hline jjs & $\begin{array}{l}\begin{array}{l}\text { Fund company's fund } \\
\text { amount. }\end{array} \\
\end{array}$ & The data come from Morningstar.com. \\
\hline $\mathrm{rq}$ & $\begin{array}{l}\text { Fund manager's average } \\
\text { tenure }\end{array}$ & The data come from Morningstar.com. \\
\hline City & Fund company's location & $\begin{array}{l}\text { Since the financial development level may affect the performance, } \\
\text { now we identify Shanghai scores } 3 \text { points, Beijing scores } 2 \text { points } \\
\text { and other capital cities score } 1 \text { point. }\end{array}$ \\
\hline cehbl & $\begin{array}{l}\text { Current fund abnormal } \\
\text { return ratio }\end{array}$ & Wind Information. \\
\hline
\end{tabular}

Flow $\quad$ Fund net inflows

$T N A_{t}$ is the fund's total net assets at $t$ moment and is the unit net asset at $t$ moment. 
Table 4. Results of descriptive statistics

\begin{tabular}{ccccc}
\hline Variable Name & Sample Size & Mean Value & Mid Value & Standard Deviation \\
\hline RAROC & 570 & -0.0193 & 0.00198 & 0.198 \\
cehbl & 570 & 0.00271 & 0.00220 & 0.0490 \\
flow & 570 & -198000000 & -52575665 & 2690000000 \\
G & 570 & 0.9 & 1 & 0.300264 \\
W & 570 & 0.533333 & 1 & 0.499326 \\
HHI & 570 & 0.408631 & 0.3678 & 0.119699 \\
size & 570 & 1332.321 & 901 & 1324.48 \\
Age & 570 & 13.23333 & 13 & 2.656678 \\
Jjs & 570 & 46.23333 & 48 & 17.98369 \\
Rq & 570 & 904.5 & 929 & 242.5901 \\
city & 570 & 1.833333 & 1.5 & 0.898316 \\
\hline
\end{tabular}

\subsection{Descriptive Statistics}

From the table above we can see that from 2010 to 2015, the abnormal return ratio is $0.271 \%$ and after the risk adjustment, the average quarterly abnormal return ratio of representative fund is $-1.93 \%$ which means that Chinese fund investment level reminds to be improved. There are two ways to improve the level, whether reduce the risk degree or increase the yield degree. As for the fund equity structure and its characters, $90 \%$ of the companies are state holding enterprise and $53 \%$ of them are joint venture enterprise. The average value of equity concentration is 0.408 and the standard deviation is 0.11 , which means the equity concentration level is pretty high and also proves the direct observation results. Most fund companies were established before ten years and the fund manager's average tenure is 904 days (nearly two and half years) which shows fund manager's job is pretty stable during the sample period, meanwhile, the average size of fund company reaches 100 billion. The city gets degree as 1.8 which means that the probability of a fund company choose Beijing and Shanghai as the company location is higher than other cities; Besides, the average fund number of one company is 46 .

\subsection{Model Establishment and Empirical Result Analysis}

2.4.1. Equity impact on fund performance model

Model Building:

In order to study fund company equity structure's effects of fund performance, we build above model for examination.

RAROC $_{\mathrm{i}, \mathrm{t}}=\alpha+\beta_{1} * \operatorname{cehbl}_{\mathrm{i}, \mathrm{t}}+\beta_{2} *$ flow $_{\mathrm{i}, \mathrm{t}}+\beta_{3} * \mathrm{HHI}_{\mathrm{i}}+\beta_{4} * \mathrm{~W}_{\mathrm{i}}+\beta_{5} * \mathrm{G}_{\mathrm{i}}$ $t$ presents time and i presents fund order

RAROC is variable being explained, and cehbl (excess return), flow (capitals flow), HHI (equity concentration), W (fund companies are controlled by state) and $\mathrm{G}$ (foreign capital inflow) are explaining variables which can measure degree of relationship between them.

Since we choose the quarterly panel data as analytical sample, the same section funds which belong to same company must have some common characteristics and this will lead to cross sectional heteroscedasticity. We select the Eviews 8.0 as measuring software and we can choose the cross sectional weights at the Weight column, which can reduce the heteroscedasticity influences of cross-sectional data by the use of generalized least squares method (GLS).

Empirical result analysis

Table 5. Regression result 1

\begin{tabular}{ccc}
\hline & Coefficient & P value \\
\hline \multirow{2}{*}{ Cehbl } & 0.517140 & 0.0000 \\
& $(9.073840)$ & \\
Flow & $2.02 \mathrm{E}-12$ & 0.2001 \\
& $(1.282752)$ & \\
HHI & 0.016227 & 0.0465 \\
& $(2.322748)$ & \\
W & -0.023378 & 0.0002 \\
& $(-3.770915)$ & 0.0023 \\
G & 0.014680 & \\
& $(3.066273)$ & 0.0423 \\
Constant Term & -0.012440 & \\
R-squared & $(-2.802410)$ & \\
\hline
\end{tabular}

Note: the value in parentheses is represents for $t$ value.

Results analysis

The square $\mathrm{R}$ is equal to 0.731608 , which is bigger than 0.5 and this means the multiple regression is acceptable and proves the explaining ability of the model.

Firstly, we can find that the excessive return ratio has a strong positive correlation with explained variable RAROC. After check the table we can know that when each group's included observations equal to 19 , while the $t$ value is bigger than 2.1, so it gets a better explanatory power. However, the $t$ value of this group equal to 9.07 and the $p$ value nearly equal to 0 which means the fitting degree between excessive return ratio and RAROC are very high. Since the excessive return ratio is directly deriving from the fund company's evaluation part of Wind database, high fitting degree means that RAROC's ability of evaluating fund performance is quite strong and feasible.

Secondly, as for the net capital flow, $t$ value is less than 2.1 while the $p$ value is bigger than 0.1 which means that 
explaining variable has connection with fund performance but does not have enough explanatory power. If only regarding this as the explanatory variable, using the time-changing variable to explain RAROC may lead to a wrong result and this is the reason why we introduce two groups of explanatory variables which may be related to RAROC.

Thirdly, the result of equity structure concentration is nearly accorded with the expecting demand. Although the $\mathrm{t}$ value is not as high as excessive return ratio but 2.3 is bigger than 2.1, the results show slight strong explanatory power. Meanwhile, the $\mathrm{p}$ value is equal to 0.047 , which is smaller than 0.05 and this is also acceptable. The HHI index coefficient in this model is 0.016 which shows a positive correlation and this means that the higher the equity structure concentration is, the better the fund performance is. This kind of result is agreed well with the theoretical analysis above. The reason behind back is that high concentration of equity structure can reduce the phenomenon of free riding. Considering their own benefits and long term popularity, the main shareholders will improve the management level and increase some incentive means. What's more, the concentration of equity structure is also benefit for making decisions and lowering management cost, which is also a way to improve fund performance level.

Fifthly, the result of introducing foreign capitals is the most unexpected part. The $\mathrm{t}$ value equal to 3.7 and the $\mathrm{p}$ value equal to 0.0002 , which both show that the variables have influence on fund performance and the most unexpected result is coefficient, which equal to -0.02 . Although we have been discussed in the theoretical part that the introducing of foreign capitals may not applicable at domestic market according to its immaturity and characteristic, but the huge coefficient is still beyond calculation. However, this kind of result shows the current situation as the total amount of fund companies grows every month, the amount of joint venture company have decreased. On the one hand, foreign capitals can't adapt Chinese investment environment. On the other hand, the guidance of government plays a more important role in the current Chinese funds (or mean financial market) than international management experience, since it's still under the adaptive phase.

\subsubsection{Model of regional feature's influence on fund performance}

\section{Model Establishment}

In order to find out whether some fund company's features can affect its fund performance or not, we use the above model to conduct the tests.

$$
\begin{gathered}
\text { RAROC }_{\mathrm{i}, \mathrm{t}}=\alpha+\beta_{1} * \operatorname{cehbl}_{\mathrm{i}, \mathrm{t}}+\beta_{2} * \operatorname{city}_{\mathrm{i}}+\beta_{3} * \operatorname{age}_{\mathrm{i}}+\beta_{4} * \operatorname{size}_{\mathrm{i}}+\beta_{5} * \mathrm{jjs}_{\mathrm{i}}+ \\
+\beta_{6} * \mathrm{rq}_{\mathrm{i}}
\end{gathered}
$$

t presents time and i presents fund order

Considering that the flow value in the above model can't match the RAROC value very well so that in this model we only select the abnormal return ratio whose fitting degree is high as one of the parameters. Also, we can use the feasible generalized least squares method (GLS) to reduce the heteroscedastic influence of cross-section data.

\section{Empirical Results}

Table 6. Regression result 2

\begin{tabular}{ccc}
\hline & Coefficient & P value \\
Cehbl & 0.497195 & \\
& $(8.659454)$ & 0.0000 \\
City & 0.012980 & 0.0012 \\
Age & $(3.250859)$ & \\
Size & -0.000948 & 0.0264 \\
& $(-2.982337)$ & 0.3200 \\
Jjs & $2.74 \mathrm{E}-06$ & \\
& $(0.995317)$ & 0.7144 \\
rq & $8.26 \mathrm{E}-05$ & \\
& $(0.366163)$ & 0.0761 \\
Constant Term & $1.34 \mathrm{E}-05$ & \\
R-squared & $(2.186004)$ & 0.0756 \\
\hline
\end{tabular}

Note: the value in parentheses is represents for $t$ value.

Result analysis

The square $\mathrm{R}$ is equal to 0.731608 , which is bigger than 0.5 and this means the multiple regression is acceptable and proves the explaining ability of the model.

Firstly, regression test results of model show that the fund company's total size and fund number do not have bigger impact on fund performance since $t$ value and $p$ value are both rejected. To analyze the reason, one conjecture is that the fund performance itself has no connection with the fund company's total size. With the increasing of scale expansion, the popularity of industries may rise but it will diffuse more attention at the same time; Another conjecture is that the increasing of fund company's total size is connected with fund number increase, which means the fund performance may be influenced by each fund's average size instead of total size or total number.

Secondly, the city brings higher mark. Since the $t$ value is equal to 3 and the $p$ value is equal to 0.0012 , the city factor becomes one of the influence factors of fund performance. From this result we can see that one city's financial environment, business's hardware and the concentration degree are all the extra points of fund product's performance.

Thirdly, fund manager's average tenure plays an active role in the whole advancement of fund performance improvement and as we mentioned in the descriptive statistics part, the average tenure of fund manager is two and half a year. Although the $t$ value is exactly equal to 2.1 and $p$ value is between 0.05 and 0.1 , the result still didn't show any strong correlation. But the result also showed a positive correlation as the longer tenure the fund manager has, the 
better they are good at making long term investment and management decisions, which is easier to adapt personal investment style with fund style.

Fourthly, it's found that the establishment date of fund company was insignificantly negative correlated with fund performance. One reason is that Chinese newborn funds may hire some strong management teams to achieve excellent performance in short term, to create Chinese brand and enhance its competitiveness. Another reason is that current old domestic fund company's management fall behind. Although it may have some marketing influential power, what investor identities is the ability of fund management so that the old fund companies should improve the management level by using others' management measures as references to enhance their own ability.

\section{Conclusions and Enlightenments}

After the theoretical and empirical study, the research conclusions are summarized as follows.

Firstly, the equity structures do have an impact on the company's fund performance and the effect can be interpreted as an approximate systematic effects. The concentration of equity structures have a positive effect on improving fund performances, and it's beneficial to making decisions, reducing management costs and free-riding behaviors so that fund company can concentrate more on developing business and enhancing performance level.

Secondly, the fund companies whose final largest shareholder is state have higher performance level than non-state owned holding fund companies and this is the manifestation of 'the helping hand of national resources'.

Thirdly, the performances of Chinese-foreign joint venture companies are lower than normal Chinese companies, which mean that foreign capital does not exert expectation effects. The reason behind the phenomenon is that current Chinese funds is in the stage which still under powerful control of government, foreign capital's management concepts advantages are not fully exerted.

Fourthly, as for the related company characteristics, the total fund size and fund number has no effect on fund performance. On the contrary, the fund company's management method and investment philosophy may fall behind the newborn company if it's founded early, which will cause the fund performance level lower than others.

Fifthly, the longer the fund manager's average tenure is, the higher the fund performance level is. Of course, short tenure and high mobility is not helpful in making investment strategy and accumulating experiences.

Sixthly, the performance of fund companies is also affected by financial environments which lead to the obvious fact that the location will have an impact on fund performance. As the finance center of China, Shanghai has the highest performance level and the second is Beijing which is the political center.

The results of this research have certain guideline for general investors, fund industries and regulators. Through the facts which are explored in this paper, general investors can define investment scope and improve investment effects by some visual standards. Some conflicts of equity structure can be dealt with by combination of fund companies' merits and demerits, which can improve control power of joint venture company and make long-term profits together. As for the regulators, the research results can help them improve macroscopic management level, accelerate the localization process of foreign capital, adapt to Chinese investment environment and make Chinese funds meet the international standards.

\section{Appendix I}

\begin{tabular}{|c|c|c|}
\hline Fund company & Shareholder & Stock share \\
\hline Baoying Fund Management Co.,Ltd. & China Railway Trust Co.,Ltd. & $75.00 \%$ \\
\hline & China Foreign Economy And Trade Trust Co.,Ltd & $25.00 \%$ \\
\hline Bosera Asset Management Co.,Ltd. & China Merchants securities Corp. & $49.00 \%$ \\
\hline & China Great Wall Asset Management Corporation & $25.00 \%$ \\
\hline & Jingan Equity Investment Co.,Ltd. & $12.00 \%$ \\
\hline & Tianjin Port(Group) Co.,Ltd. & $6.00 \%$ \\
\hline & Shanghai Shengye Equity Investment Fund Co.,Ltd. & $6.00 \%$ \\
\hline Great Wall Fund Management Co.,Ltd. & Guangsha Construct Group Co.,Ltd. & $2.00 \%$ \\
\hline & China Great Wall Securities Co., Ltd. & $47.06 \%$ \\
\hline & Zhongyuan Trust Co., Ltd. & $17.65 \%$ \\
\hline & Orient Securities Co., Ltd. & $17.65 \%$ \\
\hline Da Cheng Fund Management Co., Ltd & Zhongtai Trust Investment Co., Ltd. & $17.65 \%$ \\
\hline & China Galaxy Investment Management Co., Ltd. & $25.00 \%$ \\
\hline & Everbright Securities Co., Ltd. & $25.00 \%$ \\
\hline & Guangdong Securities Co., Ltd. & $2.00 \%$ \\
\hline
\end{tabular}




\begin{tabular}{|c|c|c|}
\hline \multirow[t]{4}{*}{ Fullgoal Fund Management Co.,Ltd } & Shenyin Wanguo Securities Co., Ltd. & $27.77 \%$ \\
\hline & (BMO)Bank of Montreal & $27.77 \%$ \\
\hline & Haitong Securities Co., Ltd. & $27.77 \%$ \\
\hline & Shangdong International Trust Investment Co., Ltd. & $16.67 \%$ \\
\hline \multirow[t]{5}{*}{ GF Fund Management Co., Ltd. } & GF Fund Securities Co., Ltd. & $51.13 \%$ \\
\hline & $\begin{array}{l}\text { Shenzhen Qianhaixiang River Financial Holding Group } \\
\text { Co., Ltd. }\end{array}$ & $15.76 \%$ \\
\hline & Fiber Home Co., Ltd. & $15.76 \%$ \\
\hline & Kangmei Pharmaceutical Co., Ltd. & $9.46 \%$ \\
\hline & Canton Venture Capital Co., Ltd. & $7.88 \%$ \\
\hline \multirow[t]{3}{*}{ GuoTai Asset Management Co., Ltd. } & China Jianyin Investment Ltd. & $60.00 \%$ \\
\hline & Generali Group(Italy) & $30.00 \%$ \\
\hline & China electric power finance Co., Ltd. & $10.00 \%$ \\
\hline \multirow[t]{2}{*}{ UBS SDIC Fund Management Co., Ltd. } & SDIC Trust Co., Ltd. & $51.00 \%$ \\
\hline & Union Bank of Switzerland Co., Ltd. & $49.00 \%$ \\
\hline \multirow[t]{5}{*}{ Hua An Fund Management Co.,Ltd } & $\begin{array}{c}\text { Shanghai Jingjiang International Investment } \\
\text { Management Co., Ltd. }\end{array}$ & $20.00 \%$ \\
\hline & Shanghai International Trust Co., Ltd. & $20.00 \%$ \\
\hline & Shanghai Industrial Investment(Group) Co., Ltd. & $20.00 \%$ \\
\hline & Shanghai Electric Group Company Limited & $20.00 \%$ \\
\hline & Guo Tai Jun'an Investment Management Co., Ltd. & $20.00 \%$ \\
\hline \multirow[t]{2}{*}{ Fortune SG Fund Management Co., Ltd. } & Huabao Trust Co., Ltd. & $51.00 \%$ \\
\hline & Lyxor Asset Management Co., Ltd. & $49.00 \%$ \\
\hline \multirow[t]{3}{*}{ Huangshang Fund Management Co., Ltd. } & Hualong Securities Co., Ltd. & $46.00 \%$ \\
\hline & China Huadian Finance Corporation Limited & $34.00 \%$ \\
\hline & Jigang Group Co., Ltd. & $20.00 \%$ \\
\hline \multirow[t]{5}{*}{ China Asset Management Co.,Ltd } & CITIC Securities Co., Ltd. & $62.20 \%$ \\
\hline & Shangdong Economic development investment company & $10.00 \%$ \\
\hline & Qindao Haipeng Technology Investment Co., Ltd. & $10.00 \%$ \\
\hline & Power Corporation of China & $10.00 \%$ \\
\hline & South Industry Assets Management Co., Ltd. & $7.80 \%$ \\
\hline \multirow[t]{3}{*}{ China Universal Asset Management Co.,Ltd } & Orient Securities Co., Ltd. & $47.00 \%$ \\
\hline & Wenhui Xinmin United Press Group & $26.50 \%$ \\
\hline & CES Jingrong Holding Co., Ltd. & $26.50 \%$ \\
\hline \multirow[t]{3}{*}{ Jiashi Fund Management Co., Ltd. } & China Credit Trust Co., Ltd. & $40.00 \%$ \\
\hline & Lixin Investment Co., Ltd. & $30.00 \%$ \\
\hline & Deutsche Asset management (Asia) Limited & $30.00 \%$ \\
\hline \multirow[t]{6}{*}{ Jianxin Fund Management Co., Ltd. } & China Construction Bank Co., Ltd. & $65.00 \%$ \\
\hline & Letter Ann financial Company & $25.00 \%$ \\
\hline & China Huadian Corporation & $10.00 \%$ \\
\hline & Bank of Communications Co., Ltd. & $65.00 \%$ \\
\hline & Schroders Investment Management Co., Ltd. & $30.00 \%$ \\
\hline & China International Marine Containers(Group) Co., Ltd. & $5.00 \%$ \\
\hline \multirow[t]{4}{*}{$\begin{array}{l}\text { Invesco Great Wall Fund Management Company } \\
\text { Limited } \\
\end{array}$} & Great Wall Securities Co., Ltd. & $49.00 \%$ \\
\hline & Invesco Ltd & $49.00 \%$ \\
\hline & Kailuan(Group) Co., Ltd. & $1.00 \%$ \\
\hline & Dalian Shide Group Co., Ltd. & $1.00 \%$ \\
\hline \multirow[t]{4}{*}{ China Southern Fund Management Co., Ltd. } & Huatai Securities Co., Ltd. & $45.00 \%$ \\
\hline & Shenzhen Investment Holding Co., Ltd. & $30.00 \%$ \\
\hline & Xiamen International Trust Co., Ltd. & $15.00 \%$ \\
\hline & Xingye Securities Co., Ltd. & $10.00 \%$ \\
\hline
\end{tabular}




\begin{tabular}{|c|c|c|}
\hline \multirow{3}{*}{ Nuoan Fund Management Co., Ltd. } & China Foreign Economy and Trade Trust Co., Ltd. & $40.00 \%$ \\
\hline & Shenzhen Jielong Investment Co., Ltd. & $40.00 \%$ \\
\hline & Daheng Science and Technology Co., Ltd. & $20.00 \%$ \\
\hline \multirow[t]{3}{*}{ Penghua Fund Management Co., Ltd. } & Guosen Securities Co., Ltd. & $50.00 \%$ \\
\hline & Eurizon Asset Management Co., Ltd. & $49.00 \%$ \\
\hline & Shenzhen Beirongxin Investment Corporation & $1.00 \%$ \\
\hline \multirow[t]{2}{*}{ Rongtong Fund Management Co., Ltd. } & New Time Securities Co., Ltd. & $60.00 \%$ \\
\hline & Nikko Asset Management Co.,Ltd & $40.00 \%$ \\
\hline \multirow[t]{5}{*}{ E Fund Management Co., Ltd. } & Infore Holding Co.,Ltd & $25.00 \%$ \\
\hline & Guangfa Securities Co., Ltd. & $25.00 \%$ \\
\hline & Guangdong GFTC Co., Ltd. & $25.00 \%$ \\
\hline & Guangdong Arising Assets Management Co.,Ltd & $16.67 \%$ \\
\hline & $\begin{array}{c}\text { Guangzhou Guangyong State-owned Assets } \\
\text { Management Co.,Ltd } \\
\end{array}$ & $8.33 \%$ \\
\hline \multirow[t]{2}{*}{ China International Fund Management Co., Ltd. } & Shanghai International Trust Co., Ltd. & $51.00 \%$ \\
\hline & J.P. Morgan Asset Management (UK) Limited & $49.00 \%$ \\
\hline \multirow[t]{8}{*}{ Tianhong Assets Management Co.,Ltd } & Ant Finance Co., Ltd. & $51.00 \%$ \\
\hline & Tianjin International Trust Co., Ltd. & $16.80 \%$ \\
\hline & Junzheng energy chemical Co., Ltd. & $15.60 \%$ \\
\hline & Wuhu High Technology Investment Co., Ltd. & $5.60 \%$ \\
\hline & Xinjiang Tianrui Bofeng Equity investment partnership & $3.50 \%$ \\
\hline & Xinjiang Tianju Chenxing Equity investment partnership & $3.50 \%$ \\
\hline & $\begin{array}{c}\text { Xinjiang Tianhui Xinmeng Equity investment } \\
\text { partnership }\end{array}$ & $2.00 \%$ \\
\hline & Xinjiang Tianfu Hengji Equity investment partnership & $2.00 \%$ \\
\hline \multirow[t]{2}{*}{ Aegon-Industrial Fund Management Co.,Ltd. } & Xingye Securities Co., Ltd. & $51.00 \%$ \\
\hline & AEGON International B.V & $49.00 \%$ \\
\hline \multirow[t]{4}{*}{ Yinhua Fund Management Co., Ltd. } & Southwest Securities Co., Ltd. & $49.00 \%$ \\
\hline & First Capital Securities Co., Ltd. & $29.00 \%$ \\
\hline & Northeast Securities Co., Ltd. & $21.00 \%$ \\
\hline & Shanxi Haixin Co., Ltd. & $1.00 \%$ \\
\hline \multirow[t]{2}{*}{ China Merchants Fund Management Co.,Ltd } & China Merchants Bank Co., Ltd. & $55.00 \%$ \\
\hline & China Merchants Securities Co., Ltd. & $45.00 \%$ \\
\hline \multirow[t]{9}{*}{ Zhong ou Assets Management Co.,Ltd } & UBI Banca Cooperation Bank Limited .Ltd & $35.00 \%$ \\
\hline & Guodu Securities Co., Ltd. & $20.00 \%$ \\
\hline & Beijing Baijun Investment Co., Ltd. & $20.00 \%$ \\
\hline & Wansheng Investment Co., Ltd. & $5.00 \%$ \\
\hline & Liu Jianping & $4.90 \%$ \\
\hline & Dou Yuming & $4.90 \%$ \\
\hline & Zhou Weiwen & $4.10 \%$ \\
\hline & Xu Xin & $4.10 \%$ \\
\hline & Lu Wenjun & $2.00 \%$ \\
\hline \multirow[t]{2}{*}{ Bank Of China Investment Management Co., Ltd. } & Bank of China Limited & $83.50 \%$ \\
\hline & BlackRock Investment Management(UK)Limited & $16.50 \%$ \\
\hline \multirow[t]{3}{*}{ China Post \& Capital Fund Management Co., Ltd. } & Shouchuang Securities Co., Ltd. & $47.00 \%$ \\
\hline & China Post Group Corporation & $29.00 \%$ \\
\hline & Sumitomo Mitsui Banking Corporation & $24.00 \%$ \\
\hline
\end{tabular}




\section{Appendix II}

\begin{tabular}{|c|c|c|c|c|c|}
\hline Fund Company & City & Register Date & Size(hundred million) & Fund amount & Average Tenure \\
\hline Baoyin & Shenzhen & $2001-5-18$ & 485.58 & 17 & 3 years and 159 days \\
\hline Boshi & Shenzhen & $1998-7-13$ & 1171.73 & 65 & 2 years and 18 days \\
\hline Great Wall & Shenzhen & $2001-12-27$ & 471.81 & 27 & 2 years and 351 days \\
\hline Dacheng & Shenzhen & $1999-4-12$ & 829.37 & 55 & 1 years and 242 days \\
\hline Fuguo & Shanghai & $1999-4-13$ & 1147.02 & 60 & 2 years and 202 days \\
\hline Guangfa & Zhuhai & $2003-8-5$ & 1754.8 & 72 & 2 years and 298 days \\
\hline Guotai & Shanghai & $1998-3-5$ & 750.92 & 52 & 2 years and 281 days \\
\hline UBS SDIC & Shenzhen & 2002-6-13 & 444.21 & 41 & 1 years and 189 days \\
\hline Huaan & Shanghai & $1998-6-4$ & 802.44 & 63 & 3 years and 17 days \\
\hline Fortune SG & Shanghai & $2003-3-7$ & 783.25 & 37 & 2 years and 130 days \\
\hline Huashang & Beijing & $2005-12-20$ & 553.13 & 24 & 2 years and 63 days \\
\hline Huaxia & Beijing & $1998-4-9$ & 3455.76 & 55 & 2 years and 259 days \\
\hline Hui Tianfu & Shanghai & $2005-2-3$ & 1889.97 & 52 & 2 years and 304 days \\
\hline Jiashi & Beijing & $1999-3-25$ & 2685.93 & 73 & 2 years and 19 days \\
\hline Jianxin Fund & Beijing & 2005-9-19 & 939.64 & 53 & 2 years and 253 days \\
\hline Bocom Schroder & Shanghai & $2005-8-4$ & 470.11 & 43 & 4 years and 202 days \\
\hline $\begin{array}{c}\text { Invesco Great } \\
\text { Wall }\end{array}$ & Shenzhen & $2003-6-12$ & 590.03 & 43 & 2 years and 51 days \\
\hline South & Shenzhen & $1998-3-6$ & 1875.1 & 68 & 3 years and 68 days \\
\hline Nuoan & Shenzhen & $2003-12-9$ & 807.72 & 41 & 2 years and 205 days \\
\hline Penghua & Shenzhen & $1998-12-22$ & 886.68 & 75 & 2 years and 228 days \\
\hline Rongtong & Shenzhen & $2001-5-22$ & 551.66 & 29 & 1 year and 247 days \\
\hline E funds & Guangzhou & $2001-4-17$ & 2426.97 & 75 & 2 years and 196 days \\
\hline Shanghai Morgan & Shanghai & $2004-5-12$ & 1156.65 & 42 & 2 years and 31 days \\
\hline Tianhong & Tianjin & $2004-11-8$ & 7299.61 & 24 & 1 year and 343 days \\
\hline $\begin{array}{c}\text { Aegon-industrial } \\
\text { Fund } \\
\end{array}$ & Shanghai & $2003-9-30$ & 1116.37 & 14 & 3 years and 37 days \\
\hline Yinhua & Beijing & $2001-5-28$ & 915.32 & 49 & 2 years and 143 days \\
\hline Zhaoshang & Shenzhen & $2002-12-27$ & 1580.3 & 50 & 1 year and 291 days \\
\hline Zhongou & Shanghai & 2006-7-19 & 393.9 & 23 & 1 years and 163 days \\
\hline Zhongyin & Shanghai & $2004-8-12$ & 1289.67 & 47 & 3 years and 47 days \\
\hline $\begin{array}{c}\text { China Post } \\
\text { Capital }\end{array}$ & Beijing & $2006-5-8$ & 443.99 & 18 & 1 year and 198 days \\
\hline
\end{tabular}

[4] Qi Chen, Itay Goldstein, Wei Jiang, (2008), 'Directors' Ownership in the U.S. Mutual Fund Industry', The Journal of Finance, (6):2629 2676.

\section{REFERENCES}

[1] Gao Yuan, (2012), 'The research of fund company equity structure's influence of fund performance [D]'. School of Management of Fudan University, (1):2.

[2] Randall Morck, Masao Nakamura, Anil shivdasani, (2000),'Banks, Ownership Structure, and Firm Value in Japan', The Journal of Business, (4):539 567.

[3] Robert F.Radin, William BStevenson, (2006), 'Comparing Mutual Fund Governance and Corporate Governance', Corporate Governance: An International Review, 14(5):367 376.
[5] Li Xuefeng, Zhang Jian,(2008), 'Whether the fund company management structure have influence on fund performance', Securities Market Herald (2):54-60

[6] Zhang Bing, Wang Shi, Lin Sheng, (2008), 'Chinese fund management company equity structure and fund performance empirical study', Journal of Taiyuan Urban Vocational College (1):1-4

[7] Jiang Ping, Tian Shu, Cheung Yan-Leung, (2011), The research of equity structure and fund performance', Journal of Financial Research(16) :123-135

[8] William F Sharpe, (1966). 'Mutual Fund Performance'. 
Journal of Business. (39):119 138.

[9] J D Jobson, Bob M Korkie, (1981), 'Performance Hypothesis Testing with the Sharpe and Treynor Measures', Journal of Finance, 36(4): 889 908.

[10] Craig L Israelsen, (2005), 'Refinement to the Sharpe Ratio and Information Ratio', Journal of Asset Management, 5(6):423 427.
[11] Hui Xiaofeng, Chi Kui,(2002). 'The analysis of Chinese securities investment fund performance evaluation based on RAROC method', Quantitative \& Technical Economics (1):113-116

[12] Xu Cuiping, Shi Qinghua, (2007), 'Shi Zhenghua The fund performance evaluation model and validity check based on VaR',Finance Tribune(1):120-121 